\title{
TENAGA KESEHATAN SELAMA PANDEMI: PENTINGNYA PERAN PSYCHOLOGICAL WELL BEING SEBAGAI MEDIASI QUALITY OF WORK LIFE DAN STRES KERJA TERHADAP PERCEIVED PRODUCTIVITY DALAM MASA PANDEMI COVID-19 DI RUMAH SAKIT SWASTA JAKARTA
}

\author{
Yohanes Ariyanto Seno, Rina Anindita, Idrus Jus'at \\ Universitas Esa Unggul, Jakarta, Indonesia \\ Email: yohanesseno22@gmail.com,rina.anindita@esaunggul.ac.id,idrus.jusat@esaunggul.ac.id
}

\begin{tabular}{|c|c|}
\hline INFO ARTIKEL & ABSTRAK \\
\hline $\begin{array}{l}\text { Diterima } \\
5 \text { Januari } 2022 \\
\text { Direvisi } \\
\text { 15 Januari } 2022 \\
\text { Disetujui } \\
\text { 25 Januari 2022 } \\
\text { Kata Kunci: } \\
\text { perceived } \\
\text { productivity; quality } \\
\text { of work life; stres } \\
\text { kerja; psychological } \\
\text { well being }\end{array}$ & $\begin{array}{l}\text { Memasuki awal tahun } 2020 \text { kondisi eksternal secara global di beberapa } \\
\text { belahan dunia mengalami pandemi covid-19 dan terkhususnya di } \\
\text { Indonesia kasus ini mulai meningkat di bulan Februari } 2020 \text {. Untuk } \\
\text { menanggapi keadaan pandemi virus covid-19 di Indonesia yang terus } \\
\text { meningkat dengan masif, maka membutuhkan tenaga kesehatan sebagai } \\
\text { garda terdepan. Rumah sakit dalam memberikan pelayanan terkait covid- } \\
19 \text { perlu memperhatikan aspek yang dapat mendukung produktifitas } \\
\text { tenaga kesehatan agar dapat meningkatkan perceived productivity. } \\
\text { Banyak faktor yang mempengaruhi perceived productivity, diantaranya } \\
\text { adalah quality of work life, stres kerja, psychogical well being, dan } \\
\text { sebagainya. Penelitian ini bertujuan untuk menganalisis pengaruh quality } \\
\text { of work life dan stres kerja terhadap perceived productivity pada tenaga } \\
\text { kesehatan di Rumah Sakit Swasta Jakarta dengan psychological well } \\
\text { being sebagai variabel mediasi dalam masa pandemi covid-19. Desain } \\
\text { penelitian yang digunakan adalah penelitian analisis kuantitatif dengan } \\
\text { pendekatan kausalitas. Sumber data didapat berupa data primer. Penulis } \\
\text { menggunakan metode survei dengan instrumen kuesioner yang } \\
\text { disebarkan kepada } 152 \text { orang sampel. Analisis data hasil kuesioner } \\
\text { dilakukan menggunakan SEM dan diilustrasikan melalui statistik } \\
\text { deskriptif. Hasil penelitian menunjukkan bahwa quality of work life dan } \\
\text { stres kerja memiliki pengaruh positif pada perceived productivity dengan } \\
\text { psychologicall well being sebagai mediasi pada tenaga kesehatan yang } \\
\text { bekerja dalam pandemi covid-19 di rumah sakit swasta Jakarta. Dengan } \\
\text { demikian, rumah sakit swasta Jakarta dapat lebih berfokus kepada } \\
\text { variabel penelitian ini dalam rangka perbaikan di kemudian hari. }\end{array}$ \\
\hline
\end{tabular}

\section{ABSTRACT}

Entering the beginning of 2020 external conditions globally in some parts of the world experienced a covid-19 pandemic and especially in Indonesia this case began to increase in February 2020. To respond to the state of the covid-19 virus pandemic in Indonesia which continues to increase massively, it requires health workers as the vanguard. Hospitals in providing services related to covid-19 need to pay attention to aspects that can support the productivity of health workers in order to increase perceived productivity. Many factors that affect perceived productivity, including quality of work life, work stress, psychogical well being, and so on. This study aims to analyze the effect of quality of work

\begin{tabular}{ll}
\hline How to cite: & Seno. Y. A. et.al (2022) Tenaga Kesehatan Selama Pandemi: Pentingnya Peran Psychological Well \\
& Being sebagai Mediasi Quality of Work Life dan Stres Kerja terhadap Perceived Productivity dalam \\
& Masa Pandemi Covid-19 di Rumah Sakit Swasta Jakarta. Jurnal Health Sains 3(1). \\
& https://doi.org/10.46799/jhs.v3i1.401 \\
E-ISSN: & $2723-6927$ \\
Published by: & Ridwan Institute
\end{tabular}


Tenaga Kesehatan Selama Pandemi: Pentingnya Peran Psychological Well Being sebagai Mediasi Quality of Work Life dan Stres Kerja terhadap Perceived Productivity dalam Masa Pandemi Covid-19 di Rumah Sakit Swasta Jakarta life and work stress on perceived productivity in health workers at Jakarta Private Hospital with psychological well being as a mediation variable in the covid-19 pandemic.The research design used is quantitative analysis research with a causality approach. The data source is obtained in the form of primary data. The authors used a survey method with questionnaire instruments distributed to 152 sample people. Analysis of questionnaire data is conducted using SEM and

Keywords: perceived productivity; quality of work life; stres kerja; psychological well being illustrated through descriptive statistics. The results showed that quality of work life and work stress had a positive influence on perceived productivity with psychological well being as mediation in health workers working in the covid-19 pandemic in jakarta private hospitals. Thus, Jakarta's private hospitals can focus more on these research variables in order to improve in thefuture.

\section{Pendahuluan}

Kasus penderita terkonfirmasi covid-19 di Indonesia terus meningkat dari tahun 2020. Rumah sakit sebagai penyedia fasilitas kesehatan dituntut untuk dapat memberikan pelayanan terbaik. Untuk mewujudkan pelayanan terbaik maka produktivitas kerja dari tenaga kesehatan sangat memegang peran keberhasilan ini. Produktivitas kerja seseorang dalam organisasi dapat dilihat dari perceived produktivity yang merupakan persepsi seseorang terkait pencapaian kinerja yang sudah dicapai dalam organisasi (Mathis \& Jackson, 2006). Tujuan utama dalam strategi manajemen sumber daya manusia adalah pencapaian produktivitas kerja yang maksimal, oleh karena itu penting untuk memahami faktor-faktor yang mempengaruhi perceived productivity (Robbins et al., 2009). Perceived productivity yang tinggi akan mendapatkan banyak manfaat yang signifikan, seperti peningkatan loyalitas karyawan, adanya engagement/keterikatan yang kuat dengan organisasi, serta meningkatkan pendapatan dan profit perusahaan (Gibson, 2011).

Sekumpulan persepsi karyawan mengenai rasa aman dalam bekerja, kepuasan kerja, dan kondisi untuk dapat bertumbuh dan berkembang sebagai manusia kita kenal dengan quality of worklife.. Faktor inilah yang menjadi salah satu kunci dari seseorang untuk meningkatkan perceived productivity dalam organisasi (Cascio, 2006).
Salah satu faktor lain yang dianggap berpengaruh terhadap seseorang untuk meningkatkan perceived productivity adalah stres kerja. Ketika seseorang memiliki stres kerja yang rendah maka akan meningkatkan perceived productivity dimana dapat disimpulkan akan memberikan produktivitas kerja yang baik bagi organisasi dan karyawan itu sendiri (Cooper \& Uzun, 2019).

Psychological well being merupakan usaha untuk mencapai kesempurnaan yang mewakili potensi diri seseorang (Ryff \& Keyes, 1995). Hasil studi menyimpulkan bahwa psychological well being memiliki pengaruh positif terhadap perceived productivity.

Rumah Sakit Swasta Jakarta sebagai tempat melakukan penelitian adalah rumah sakit yang melakukan pelayanan covid-19. Karyawan yang bekerja di rumah sakit ini terdiri dari tenaga kesehatan dan tenaga non kesehatan yang saling bekerja sama untuk memberikan pelayanan terbaik kepada pasien.

Menurut data indikator mutu ruangan menunjukkan bahwa Indikator kerja unit yang terkait dengan kepuasan pasien (patient satisfaction) di bulan Agustus 2020 masih di bawah standar seperti admission time dengan target $\leq 90$ menit aktualnya 186 menit, rencana pemulangan pasien private dengan target $70 \%$ aktualnya $30 \%$, dan rencana pemulangan pasien dari emergency target $\leq$ 120 menit aktualnya 140 menit. Saat dilakukan wawancara kepada 8 tenaga 
kesehatan mengatakan mengalami hambatan dalam melakukan beberapa prosedur invasif terkait pelayanan covid-19 sehingga mempengaruhi waktu pelaksanaan prosedur sebagaimana mestinya dan beberapa kali mengalami kegagalan dalam melakukan prosedur invasif dan hal ini mempengaruhi produktivitas kerja.

Saat dilakukan obervasi di lapangan ditemukan bahwa adanya keterbatasan pergerakan dari tenaga kesehatan karena menggunakan APD (alat pelindung diri) yang lebih kompleks, adanya hambatan motorik dalam melakukan prosedur kepada pasien, dan hambatan dalam melaksanakan kebutuhan dasar seperti makan, minum, dan kebutuhan eliminasi. Melihat keadaan demikian tentunya akan berdampak pada kinerja/produktivitas tenaga kesehatan dalam melaksanakan pekerjaannya dimana menyebabkan penurunan kualitas dan kuantitas pekerjaan.

Saat dilakukan observasi di lapangan terkait pelayanan covid-19 didapatkan adanya komplain pasien terkait kesalahan penginputan identitas pasien, kesalahan penginputan hasil PCR dan serologi, dan lamanya mendapatkan hasil pemeriksaan sesuai dengan waktu yang telah ditentukan.

Berdasarkan sebaran kuesioner ditemukan adanya persepsi quality of work life dari tenaga kesehatan saat bekerja dalam masa covid-19 yang cenderung kurang setuju dengan presentase sebesar 57\%. Dari hasil kuesioner menunjukkan cenderung kurang setuju terhadap quality of work life lebih banyak ditunjukkan dari ketidakikutsertaan dalam pengambilan keputusan, kurangnya pelatihan untuk pengembangan kemampuan dan keterampilan terkait covid-19, dan kurang jelasnya sistem kompensasi yang diterima oleh tenaga kesehatan terkait dengan pelayanan covid-19.

Hasil wawancara kepada 8 tenaga kesehatan mengatakan bahwa kompensasi seperti pemeriksaan serologi berkala belum berjalan semestinya, pemberian vitamin tambahan belum berjalan, penjelasan terkait medical benefit terkait covid-19 belum disosialisasikan dengan baik, dan kurangnya kenyamanan terkait lingkungan kerja terkait covid-19.

Hasil wawancara yang dilakukan kepada 8 tenaga kesehatan mengatakan bahwa dalam menjalankan pekerjaan dalam masa pandemi covid-19 menyebabkan gangguan dalam pemikiran akan risiko tertularnya virus covid-19 saat bekerja dan pemikiran ini terkadang berdampak pada gangguan fisiologis seperti sulit tidur, penurunan nafsu makan, dan penurunan konsentrasi saat bekerja. Adanya kecemasan tenaga kesehatan di rumah sakit dalam bekerja selama dalam pandemi covid-19 yang disebabkan karena adanya peningkatan risiko tertular covid-19, cemas karena adanya anggota keluarga di rumah yang kemungkinan dapat tertular, kecemasan karena peningkatan kontak dengan pasien beresiko covid-19, dan cemas karena kemungkinan tertular saat menggunakan transportasi umum ke rumah sakit.

Penelitian ini bertujuan agar rumah sakit dapat mengetahui pengaruh quality of work life, stres kerja, dan psychological well being terhadap perceived productivity pada tenaga kesehatan dalam masa pandemi covid19, sehingga rumah sakit dapat mengetahui upaya meningkatkan quality of work life, menurunkan stres kerja, meningkatkan psychological well being, agar perceived productivity akan meningkat. Dengan latar belakang tersebut, maka penelitian ini mengambil judul "Pengaruh quality of work life dan stres kerja terhadap perceived productivity dengan psychological well being sebagai mediasi pada tenaga kesehatan yang bekerja dalam masa pandemi covid-19 di Rumah Sakit Swasta Jakarta.

Perceived productivity menurut (Mathis \& Jackson, 2006) yaitu persepsi seseorang terkait pencapaian kerja di dalam 
Tenaga Kesehatan Selama Pandemi: Pentingnya Peran Psychological Well Being sebagai Mediasi Quality of Work Life dan Stres Kerja terhadap Perceived Productivity dalam Masa

Pandemi Covid-19 di Rumah Sakit Swasta Jakarta

organisasi. Indikator perceived productivity yang digunakan dalam penelitian ini adalah kualitas kerja, kuantitas kerja, dan ketepatan waktu. (Cascio, 2006) mendefinisikan quality of work life sebagai persepsi karyawan mengenai rasa aman dalam bekerja, kepuasan kerja, dan kondisi untuk dapat bertumbuh dan berkembang. Di dalam penelitian ini, pengukuran quality of work life menggunakan 8 indikator antara lain partisipasi karyawan, pengembangan karir, penyelesaian konflik, komunikasi, kemanan dalam bekerja, keselamatan, kesehatan, dan kompensasi. Menurut (Cooper \& Uzun, 2019) stres kerja sebagai tanggapan atau proses internal atau eksternal yang mencapai tingkat ketegangan fisik dan psikis sampai pada batas atau melebihi kemampuan seseorang. Stres kerja dalam penelitian ini diukur dengan menggunakan 4 indikator yaitu kondisi pekerjaan, peran, komunikasi interpersonal, dan struktur organisasi. (Ryff \& Keyes, 1995) mendefinikan psychological well being sebagai usaha untuk mencapai kesempurnaan yang mewakili potensi diri seseorang. Indikator psychological well being yang digunakan dalam penelitian ini antara lain penerimaan diri, hubungan positif dengan orang lain, memiliki tujuan hidup, mandiri, mampu mengendalikan lingkungan, dan tumbuh secara personal.

Pengaruh quality of work life terhadap psychological well being pada tenaga kesehatan di Rumah Sakit secara parsial

Berbagai faktor dapat berpengaruh terhadap peningkatan kemampuan sumber daya manusia diantaranya quality of work life dan psychological well being. Berdasarkan teori (Robbins et al., 2009) dijelaskan bahwa quality of work life yang positif akan meningkatkan psychological well being karyawan dalam bekerja. Dimana dengan peningkatan quality of work life maka akan meningkatkan psychological well being karyawan dalam bekerja. Berdasarkan hasil penelitian yang dilakukan oleh (Abdurrahman et al., 2015) diketahui bahwa variabel quality of work life berpengaruh positif terhadap psychological well being karyawan. Dalam penelitian yang akan dilakukan mempunyai dugaan sementara atau hipotesis bahwa quality of work life berpengaruh psychological well being pada tenaga kesehatan di Rumah Sakit.

H1: Berdasarkan teori dan hasil penelitian yang digunakan dalam penelitian ini maka dapat dikatakan bahwa quality of work life memiliki pengaruh positif terhadap psychological well being

Pengaruh stres kerja terhadap psychological well being tenaga kesehatan di Rumah Sakit secara parsial.

Berdasarkan teori yang dijelaskan oleh (Ryff \& Keyes, 1995) bahwa stres kerja yang dialami oleh karyawan dalam perusahaan akan berpengaruh terhadap kesejahteraan psikologis (psychological well being), dimana karyawan yang mengalami stres kerja yang tinggi akan memiliki psychological well being yang rendah. Berdasarkan hasil penelitian yang dilakukan oleh Saheed (2018) diketahui bahwa variabel stres kerja berpengaruh positif terhadap psychological well being karyawan. Dalam penelitian yang akan dilakukan mempunyai dugaan sementara atau hipotesis bahwa stres berpengaruh psychological wellbeing pada tenaga kesehatan di Rumah Sakit.

$\mathrm{H} 2$ : Berdasarkan teori dan hasil penelitian yang digunakan dalam penelitian ini maka dapat dikatakan bahwa stres kerja memiliki pengaruh positif terhadap psychological well being

Pengaruh psychological well being terhadap perceived productivity pada proesional pemberi asuhan di Rumah Sakit secara parsial.

Berdasarkan teori yang dijelaskan oleh (Ryff \& Keyes, 1995) bahwa psychological well being yang baik maka akan berpengaruh terhadap perceived productivity dalam bekerja, dimana dengan adanya kesejahteraan 
psikologis karyawan yang meningkat akan meningkatkan perceived productivity dalam bekerja. Berdasarkan penelitian yang dilakukan oleh (Alwi, 2016) didapatkan bahwa adanya hubungan antara psychological well being dan job performance. Dalam penelitian yang akan dilakukan mempunyai dugaan sementara atau hipotesis bahwa Dalam penelitian yang akan dilakukan mempunyai dugaan sementara atau hipotesis bahwa psychological well being berpengaruh pada perceived productivity pada tenaga kesehatan di Rumah Sakit.

H3: Berdasarkan teori dan hasil penelitian yang digunakan dalam penelitian ini maka dapat dikatakan bahwa psychological well being memiliki pengaruh positif terhadap perceived productivity.

Pengaruh quality of work life terhadap perceived productivity pada tenaga kesehatan di Rumah Sakit secara parsial.

Perusahaan yang baik dalam manajemen sumber daya manusia akan memperhatikan quality of work life karyawannya, karena dengan quality of work life yang tinggi pada karyawan maka akan meningkatkan pula perceived productivity dalam perusahaan. Berdasarkan teori yang diberikan oleh (Cooper \& Uzun, 2019) menjelaskan bahwa quality of work life berpengaruh terhadap perceived productivity. Penelitian yang dilakukan oleh (Laxman et al., 2017) menunjukkan bahwa quality of work life berpengaruh terhadap perceived productivity

dimana hasil penelitian menunjukkan bahwa karyawan yang memiliki quality of work life yang tinggi maka akan meningkatkan kinerja/produktifitas. Dalam penelitian yang akan dilakukan mempunyai dugaan sementara atau hipotesis bahwa quality of work life berpengaruh pada perceived productivity pada tenaga kesehatan di Rumah Sakit.

H4: Berdasarkan teori dan hasil penelitian yang digunakan dalam penelitian ini maka dapat dikatakan bahwa quality of work life memiliki pengaruh positif terhadap perceived productivity

Pengaruh stres kerja terhadap perceived productivity pada tenaga kesehatan di Rumah Sakit secara parsial

Stres kerja (work stres) yang dialami oleh karyawan saat bekerja merupakan bagian penting yang harus diperhatikan oleh perusahaan, karena dengan adanya peningkatan stres kerja pada karyawan maka akan menurunkan perceived productivity itu sendiri dan tentunya akan berdampak pada produktivitas perusahaan. Berdasarkan teori dari (Cooper \& Uzun, 2019) menjelaskan bahwa stres kerja berpengaruh terhadap perceived productivity. Penelitian yang dilakukan oleh (Abid et al., 2015) menunjukkan bahwa stres kerja berpengaruh terhadap perceived productivity, dimana karyawan yang mengalami peningkatan stres kerja maka akan menurunkan kinerja. Dalam penelitian yang akan dilakukan mempunyai dugaan sementara atau hipotesis bahwa stres kerja berpengaruh terhadap perceived productivity pada tenaga kesehatan di Rumah Sakit.

H5: Berdasarkan teori dan hasil penelitian yang digunakan dalam penelitian ini maka dapat dikatakan bahwa stres kerja memiliki pengaruh positif terhadap perceived productivity

Pengaruh quality of work life, stres kerja, dan psychological well being terhadap perceived productivity tenaga kesehatan di Rumah Sakit secara simultan.

Perusahaan memiliki visi dan misi untuk meningkatkan produktivitas perusahaan, oleh karena itu maka harus diperhatikan manajemen sumber daya manusia dalam perusahaan sebagai aset penting. Perceived productivity akan dipengaruhi oleh berbagai aspek diantaranya quality of work life, stres kerja, dan psychological well being. Karyawan yang memiliki quality of work life yang baik, stres kerja yang rendah, dan psychologicall well 
Tenaga Kesehatan Selama Pandemi: Pentingnya Peran Psychological Well Being sebagai Mediasi Quality of Work Life dan Stres Kerja terhadap Perceived Productivity dalam Masa

Pandemi Covid-19 di Rumah Sakit Swasta Jakarta

being yang tinggi maka akan meningkatkan perceived productivity dalam perusahaan. Penelitian yang dilakukan oleh (Bouchra et al., 2020) menunjukkan bahwa quality of work life berpengaruh terhadap perceived productivity dan dimediasi oleh psychological well being dan penelitian yang dilakukan oleh (Prateek et al., 2017) menunjukkan bahwa stres kerja berpengaruh terhadap perceived productivity yang dimediasi oleh psychological well being. Dalam penelitian yang akan dilakukan mempunyai dugaan sementara atau hipotesis bahwa quality of work life, stres kerja, dan psychological well being berpengaruh terhadap perceived productivity pada tenaga kesehatan di Rumah Sakit.

H6: Berdasarkan teori dan hasil penelitian yang digunakan dalam penelitian ini maka dapat dikatakan bahwa quality of work life, stres kerja, dan psychological well being terhadap perceived productivity secara simultan

\section{Metode Penelitian}

Penelitian ini termasuk jenis eksplanatori yang bertujuan untuk menjelaskan hubungan kausalitas (pengaruh) dan menguji hipotesis, menggunakan pendekatan kuantitatif dan berdasarkan tingkat eksplanasinya digolongkan dalam penelitian asosiatif. Pembuktian hipotesa dilakukan dengan metode survey yang mengambil sampel untuk diteliti dan menggunakan instrumen berbentuk kuesioner dengan menggunakan skala likert yang memiliki 5 pilihan jawaban, yaitu sangat tidak setuju, tidak setuju, netral, setuju, dan sangat setuju.

Populasi dalam penelitian ini adalah seluruh tenaga kesehatan di Rumah Sakit
Swasta Jakarta. Sampel pada penelitian ini adalah sejumlah tenaga kesehatan di Rumah Sakit Swasta Jakarta yang memiliki surat tanda registrasi dan melakukan pelayanan covid-19.

Pengambilan sampel dalam penelitian ini menggunakan desain non probability sampling. Penentuan responden yang dijadikan sampel dalam penelitian ini dilakukan dengan metode purposive sampling. Hal ini karena tidak seluruh tenaga kesehatan dapat dijadikan sampel.

Dibutuhkan karakteristik tertentu, yaitu rekanan kerja di RS (dokter spesialis), karyawan tenaga kesehatan rumah sakit, memiliki status sebagai karyawan tetap, memiliki jenjang pendidikan $\geq$ DIII, memiliki STR (surat tanda registrasi), dan memiliki SIP (surat ijin praktik). Jumlah sampel yang diambil adalah 152 sampel.

Dalam menguji hipotesis penelitian ini menggunakan alat analisis hipotesa dimana dalam penelitian ini menggunakan analisis jalur (path analysis) karena peneliti ingin memastikan apakah ada pengaruh quality of work life dan stres kerja terhadap perceived productivity dengan psychological well being sebagai variabel mediasi. Tujuannya adalah menerangkan pengaruh simultan dan partial seperangkat variabel sebagai variabel penyebab, terhadap variabel lainnya yang merupakan variabel akibat. Pengujian terhadap model penelitian dilakukan dengan menggunakan Structural Equation Modelling (SEM).

\section{Hasil dan Pembahasan}

Data didapatkan di Rumah Sakit Swasta Jakarta pada periode Oktober hingga November 2020. Data dikumpulkan sebanyak 152 data dan semua data lengkap.

Tabel 1

Gambaran Karakteristik Responden Penelitian

\begin{tabular}{|c|c|c|c|c|}
\hline No & Faktor & & Jumlah & $\%$ \\
\hline 1 & Jenis Kelamin & & & \\
\hline & Laki-laki & 64 & $43,1 \%$ & \\
\hline
\end{tabular}


Yohanes Ariyanto Seno, Rina Anindita, Idrus Jus'at

\begin{tabular}{|c|c|c|c|c|}
\hline & Perempuan & 88 & $57,9 \%$ & \\
\hline & TOTAL & 152 & $100 \%$ & \\
\hline \multirow[t]{7}{*}{2} & Usia & & & \\
\hline & $18-24$ & & 36 & $23 \%$ \\
\hline & $25-34$ & & 75 & $52 \%$ \\
\hline & $35-49$ & & 32 & $21 \%$ \\
\hline & $50-56$ & & 6 & $3 \%$ \\
\hline & $>56$ & & 3 & $1 \%$ \\
\hline & TOTAL & & 152 & $100 \%$ \\
\hline \multirow[t]{6}{*}{3} & Pendidikan & & & \\
\hline & DIII & & 52 & $34 \%$ \\
\hline & S1 & & 92 & $61 \%$ \\
\hline & $\mathrm{S} 2$ & & 8 & $5 \%$ \\
\hline & S3 & & 0 & 0 \\
\hline & TOTAL & & 152 & $100 \%$ \\
\hline \multirow[t]{10}{*}{4} & Profesi & & & \\
\hline & Dokter & & 16 & $11 \%$ \\
\hline & Perawat/Bidan & & 74 & $49 \%$ \\
\hline & Apoteker/TTK & & 16 & $11 \%$ \\
\hline & Analis Lab & & 11 & $7 \%$ \\
\hline & Rekam Medis & & 19 & $13 \%$ \\
\hline & Radiografer & & 8 & $5 \%$ \\
\hline & Ahli Gizi & & 2 & $1 \%$ \\
\hline & Fisioterapis & & 6 & $3 \%$ \\
\hline & TOTAL & & 152 & $100 \%$ \\
\hline
\end{tabular}

Data deskriptif responden dirangkum dalam tabel 1. menunjukkan bahwa dari 152 responden, jumlah responden terbanyak berdasarkan jenis kelamin adalah perempuan sebesar 57,9\%, jumlah responden terbanyak berdasarkan usia adalah 25-34 tahun sebesar $52 \%$, responden terbanyak berdasarkan jenjang pendidikan adalah S1 sebesar $61 \%$ dan responden terbanyak berdasarkan profesi adalah perawat/bidan sebesar $49 \%$.

a. Uji Validitas

Berdasarkan perhitungan uji validitas diketahui bahwa pernyataan seluruh variabel memiliki nilai Corrected Item - Total Correlation > $\mathrm{r}$ tabel $(0,396)$ sehingga dapat disimpulkan bahwa seluruh pernyataan valid dan artinya bahwa indikator ini baik untuk mengukur variabel laten secara tepat.

b. Uji Reliabilitas

Berdasarkan perhitungan diketahui bahwa seluruh variabel mempunyai nilai alfa cronbach 0.747-0.918 sehingga dinyatakan bahwa seluruh butir pernyataan yang ada pada setiap variabel dinyatakan reliabel atau handal.

Tabel 2

Uji Validitas dan Uji Reliabilitas

\begin{tabular}{cccc}
\hline Item & $\begin{array}{c}\text { Corected } \\
\text { item }\end{array}$ & $\begin{array}{c}\text { Corected item total-total } \\
\text { correlation }\end{array}$ & Alfa Cronbach \\
\hline QWL & 0.749 & $0.474-0.824$ & 0.918 \\
\hline SK & 0.567 & $0,413-0.745$ & 0.760 \\
\hline PWB & 0.576 & $0.479-0.681$ & 0.794 \\
\hline PP & 0.585 & $0.402-0.707$ & 0.747 \\
\hline
\end{tabular}


Tenaga Kesehatan Selama Pandemi: Pentingnya Peran Psychological Well Being sebagai Mediasi Quality of Work Life dan Stres Kerja terhadap Perceived Productivity dalam Masa

Pandemi Covid-19 di Rumah Sakit Swasta Jakarta

1. Analisis Deskriptif (Three Box Method)

Analisis deskriptif pada penelitian ini menggunakan analisis angka indeks three box method menurut (Ferdinand, 2008). Deskriptif analisis digunakan untuk mengetahui jawaban responden terhadap variabel quality of work life, stres kerja, psychological well being dan perceived productivity. Untuk mendapatkan kecenderungan jawaban responden terhadap masing-masing variabel, maka akan didasarkan pada nilai skor rata-rata (indeks) yang dikategorikan ke dalam rentang skor berdasarkan perhitungan three box method.

Batas atas rentang skor: $(200 * 5) / 5=$ 152

Batas bawah rentang skor: $(200 * 1) / 5=30,4$

Angka indeks yang dihasilkan menujukkan skor 30,4 - 152, dengan rentang sebesar 121,6. Dengan menggunakan three box method, maka rentang 121,6 dibagi menjadi tiga bagian, sehingga menghasilkan rentang untuk masing-masing bagian sebesar 40,5, dimana akan digunakan sebagai daftar interpretasi indeks sebagai berikut:

30,4 - 71: Rendah

71,1 - 111,6: Sedang

111,7 - 152: Tinggi

a. Deskripsi tentang quality of work life

Pada quality of work life untuk no 1 hingga no 24 masuk dalam kategori tinggi dengan nilai rata-rata adalah 130,2 sehingga indikator ini baik untuk mengukur indikator lainnya secara tepat. Hal ini artinya secara umum tenaga kesehatan

Rumah Sakit Swasta

Jakartamemiliki persepsi setuju bahwa quality of work life ditentukan oleh indikatorindikator yang berkaitan antara lain partisipasi karyawan, pengembangan karir, penyelesaian konflik, komunikasi, keamanan dalam bekerja, keselamatan dalam bekerja, kesehatan, dan kompensasi. Nilai pernyataan yang paling tinggi adalah "adanya sarana dan prasarana pendukung.", artinya tenaga kesehatan memiliki persepsi bahwa Rumah Sakit Swasta Jakarta mendukung dalam pekerjaan dan menjaga keamanan dan keselamatan dalam bekerja di masa pandemi covid-19. Nilai terendah adalah pernyataan "adanya pemberian reward terhadap pekerjaan yang telah dilakukan". artinya tenaga kesehatan memiliki persepsi bahwa Rumah Sakit Swasta Jakartabelum memperhatikan penghargaan kepada profesional dalm bentuk pemberian reward dalam melakukan pekerjaan dalam masa pandemi covid-19.

b. Deskripsi tentang stres kerja Pada stres kerja untuk no 1 hingga no 12 masuk dalam kategori tinggi dengan nilai ratarata adalah 121,4 sehingga indikator ini baik untuk mengukur indikator lainnya secara tepat. Hal ini artinya secara umum semua pernyataan indikator stres kerja memberikan kesan bahwa tenaga kesehatan setuju bahwa stres kerja 
ditentukan oleh indikatorindikator yang berkaitan antara lain kondisi pekerjaan, peran, hubungan interpersonal, dan struktur organisasi. Nilai pernyataan pada variabel stres yang paling tinggi adalah "saya memiliki hubungan harmonis dengan rekan kerja", artinya persepsi tenaga kesehatan memiliki hubungan yang baik kepada sesama rekan kerja/tim selama dalam bekerja dalam masa pandemi covid-19. Nilai terendah adalah pernyataan "Tugas yang saya kerjakan sesuai dengan tanggung jawab yang saya miliki"”. Hal ini berarti tenaga kesehatan menganggap bahwa pekerjaan yang dilakukan belum sesuai dengan tanggung jawab yang ada dimana tanggung jawab yang ada melebihi uraian tugas yang ada, atau dengan kata lain dalam menjalankan pekerjaan, tanggung jawab yang diberikan melebihi yang semestinya.

c. Deskripsip psychological well being

Pada kepercayaan untuk no 1 hingga no 36 masuk dalam kategori sedang dengan nilai rata-rata adalah 111,2 sehingga indikator ini baik untuk mengukur indikator lainnya secara tepat. Berdasarkan ratarata keseluruhan yang sedang dapat diartikan bahwa semua pernyataan indikator psychologicall well being memberikan kesan bahwa tenaga kesehatan cukup sesuai menggambarkan bahwa psychologicall well being ditentukan oleh indikator- indikator yang berkaitan antara lain penerimaan diri, hubungan positif dengan orang lain, memiliki tujuan hidup, mandiri, mampu mengendalikan lingkungan, dan tumbuh secara personal. Nilai pernyataan pada variabel yang paling tinggi adalah psychologicall well being "Saya memiliki hubungan yang baik dan terpercaya dengan orang lain", artinya tenaga kesehatan memiliki persepsi bahwa mereka setuju bahwa pentingnya untuk menjalin hubungan baik dengan orang lain dalam satu tim selama bekerja dalam masa pandemi covid-19. Nilai terendah adalah pernyataan "Saya mudah beradaptasi terhadap hal-hal eksternal yang mempengaruhi pekerjaan saya", artinya dengan keadaan pandemi covid-19 ini membuat para tenaga kesehatan memiliki kesulitan dalam melakukan proses adaptasi/penyesuaian diri dalam melakukan pekerjaan.

d. Deskripsi tentang perceived productivity

Pada variabel perceived productivity untuk nomor 1 hingga nomor 12 masuk dalam kategori tinggi dengan nilai ratarata adalah 136,4 sehingga indikator ini baik untuk mengukur indikator lainnya secara tepat. Berdasarkan ratarata keseluruhan yang tinggi dapat diartikan bahwa semua pernyataan indikator perceived productivity memberikan kesan bahwa tenaga kesehatan setuju bahwa perceived productivity ditentukan oleh indikatorindikator yang berkaitan antara 
Tenaga Kesehatan Selama Pandemi: Pentingnya Peran Psychological Well Being sebagai Mediasi Quality of Work Life dan Stres Kerja terhadap Perceived Productivity dalam Masa

Pandemi Covid-19 di Rumah Sakit Swasta Jakarta

lain kualitas, kuantitas, dan

ketepatan waktu. Nilai

pernyataan pada variabel

perceived productivity yang

paling tinggi adalah "Dengan

pengetahuan yang saya miliki,

saya mampu melaksanakan

pekerjaan", hal ini menandakan

bahwa tenaga kesehatan

memiliki persepsi bahwa

pengetahuan yang ada

mendukung melaksanakan

pekerjaan dalam masa pandemi

covid-19. Nilai terendah dari variabel perceived productivity adalah "Tingkat pencapaian volume kerja yang saya hasilkan telah sesuai dengan harapan yang diberikan" yang artinya para tenaga kesehatan memiliki persepsi bahwa harapan yang ingin dicapai cukup tinggi tidak sebanding dengan pencapaian volume kerja yang dihasilkan oleh tenaga kesehatan yang bekerja selama dalam masa pandemi covid-19.

Tabel 3

Rekapitulasi Three Box

\begin{tabular}{|c|c|c|c|c|c|}
\hline \multirow{2}{*}{ Variabel } & \multicolumn{3}{|c|}{ Indikator } & \multirow{2}{*}{$\begin{array}{c}\text { Indeks } \\
\text { Rata-rata } \\
\end{array}$} & \multirow{2}{*}{ Kategori } \\
\hline & Rendah & Sedang & Tinggi & & \\
\hline $\begin{array}{l}\text { Quality of work } \\
\text { life }\end{array}$ & 0 & 3 & 21 & 130,2 & Tinggi \\
\hline Stres kerja & 0 & 2 & 10 & 121,4 & Tinggi \\
\hline $\begin{array}{l}\text { Psychological } \\
\text { Well Being }\end{array}$ & 0 & 7 & 29 & 111,2 & Sedang \\
\hline $\begin{array}{l}\text { Perceived } \\
\text { Productivity }\end{array}$ & 0 & 1 & 11 & 136.4 & Tinggi \\
\hline
\end{tabular}

Confirmatory Factor Analysis (CFA) digunakan untuk memeriksa lebih lanjut validitas item yang mengukur semua konstruk dalam penelitian ini. CFA digunakan untuk mendapatkan model fit untuk model pengukuran dan untuk menguji validitas konvergen dan diskriminan dari konstruk dalam penelitian. Kriteria model yang dianggap fit meliputi: (1) Normed Chi-square $\left(\chi^{2} / \mathrm{df}\right)$ kurang dari 3, (2) Root Mean Square Error of Approximation (RMSEA) kurang dari 0,08, (3) Expected Cross Validation Index (ECVI) model sedikit lebih kecil dari ECVI saturated model dan selisihnya jauh lebih besar lagi dari ECVI independence model
(4) Akaike Information Criterion (AIC) dan Consistent Akaike Information Creterion (CAIC) model sedikit lebih kecil dari AIC dan CAIC saturated model dan selisihnya jauh lebih besar lagi dari AIC dan CAIC independence model (5) Fit Index melebihi 0,90 (6) Critical N lebih dari 200 (7) Goodness of fit (GFI) lebih besar sama dengan 0,90. Hasil uji CFA memberikan nilai Chi Square sebesar 308,203 dengan nilai $\mathrm{p}=0,000$. Nilai Cmin/df memberikan nilai 1,863 (kurang dari $\square$ 2,00), kemudian nilai RMSEA sebesar 0,067 (kurang dari $\square$ 0,08). Walaupun tampak bahwa $\mathrm{p}$ dibawah nilai taraf signifikansi $\quad(p \leq 0,05)$ yang 
menyatakan bahwa terdapat perbedaan antara matriks kovarians sampel namun masih dapat diterima secara marjinal. Nilai GFI sebesar dan AGFI diterima secara marjinal karena juga dibawah nilai yang disarankan $(\square 0,90)$. Nilai TLI sebesar 0,776 dan CFI sebesar 0,804 (melebihi nilai $\square 0,90$ ) diterima secara marjinal, artinya secara keseluruhan model dapat dapat diterima secara marjinal sehingga hasil analisis CFA pada penelitian ini masih memenuhi syarat yang diharapkan, dan dapat dilanjutkan.

Hasil menunjukkan bahwa model yang digunakan dapat diterima. Nilai CMIN/DF sebesar 1,683 menunjukkan suatu model persamaan struktural yang baik. Indeks pengukuran RMSEA berada pada rentang nilai yang diharapkan yaitu $\leq 0,08$ yaitu 0,067. Meskipun chisquare, probability level, CFI, TLI diterima secara marjinal. Berdasarkan hasil analisis tersebut maka model dinyatakan layak secara marjinal. Dari beberapa uji kelayakan model dikatakan layak jika paling tidak salah satu metode uji kelayakan model terpenuhi (S. Haryono, 2016).

Dalam suatu penelitian empiris, seorang peneliti tidak dituntut untuk memenuhi semua kriteria goodness of fit, akan tetapi tergantung judgment masing-masing peneliti. Nilai chi-square dalam penelitian ini adalah 308,023. Joreskog dan Sobron dalam (A. Haryono et al., 2021) mengatakan bahwa chisquare tidak dapat digunakan sebagai satu-satunya ukuran kecocokan keseluruhan model, salah satu sebabnya adalah karena chi-square sensitif terhadap ukuran sampel. Ketika ukuran sampel meningkat, nilai chi-square akan meningkat pula dan mengarah pada penolakan model meskipun nilai perbedaan antara matriks kovarian sampel dengan matrik kovarian model telah minimal atau kecil. Chisquare juga berhubungan erat dengan nilai degree of freedom, bila degree of freedom lebih besar maka akan berpengaruh pada nilai chi-square. Nilai degree of freedom dalam penelitian cukup besar yakni 183 sehingga mempengaruhi nilai chi-square. Dari hasil output model pada Tabel 4 untuk kriteria uji kesesuaian model, beberapa kriteria berada pada nilai marginal.

Nilai marginal adalah kondisi kesesuaian model pengukuran di bawah kriteria ukuran absolute fit maupun incremental fit, namun masih dapat diteruskan pada analisis lebih lanjut karena dekat dengan kriteria good fit (Kusuma \& Sugiarsi, 2010). 
Tenaga Kesehatan Selama Pandemi: Pentingnya Peran Psychological Well Being sebagai Mediasi Quality of Work Life dan Stres Kerja terhadap Perceived Productivity dalam Masa

Pandemi Covid-19 di Rumah Sakit Swasta Jakarta

Tabel 4

Hasil Goodnes of Fit

\begin{tabular}{cccc}
\hline Goodness of index & Cut-off Value & $\begin{array}{c}\text { Hasil } \\
\text { Estimasi }\end{array}$ & Keterangan \\
\hline Chi-square $(\chi 2)$ & $\begin{array}{c}\text { Diharapkan } \\
\text { kecil }\end{array}$ & 308,023 & Marjinal \\
\hline $\begin{array}{c}\text { Significance } \\
\text { Probability (p) }\end{array}$ & $\geq 0.05$ & 0,000 & Marjinal \\
\hline RMSEA & $\leq 0.08$ & 0,067 & Baik \\
\hline GFI & $\geq 0.90$ & 0,847 & Marjinal \\
\hline AGFI & $\geq 0.90$ & 0,807 & Marjinal \\
\hline CMIN/DF & $\leq 2.00$ & 1,683 & Baik \\
\hline TLI & $\geq 0.95$ & 0,776 & Marjinal \\
\hline CFI & $\geq 0.95$ & 0,804 & Marjinal \\
\hline
\end{tabular}

Perangkat lunak statistik (SEM-AMOS) digunakan untuk menguji model struktural penelitian ini. Menurut (Hair et al., 2014), SEM biasanya digunakan oleh para peneliti untuk memeriksa kesesuaian model secara keseluruhan dan untuk menguji kekuatan relatif dari jalur kausal individu. Hasil dari jalur kausal disajikan pada Tabel 5.

Tabel 5

Hasil Pengujian Hipotesis

\begin{tabular}{clcc}
\hline Hipotesis & \multicolumn{1}{c}{ Pengaruh } & P Value & \multirow{2}{*}{ Ket. } \\
\hline H1 & $\begin{array}{l}\text { Quality of Work Life } \rightarrow \text { Psychological Well } \\
\text { Being }\end{array}$ & 0,521 & Ditolak \\
\hline H2 & Stres Kerja $\rightarrow$ Psychological Well Being & 0,000 & Diterima \\
\hline H3 & $\begin{array}{l}\text { Psychological Well Being } \rightarrow \text { Perceived } \\
\text { Productivity }\end{array}$ & 0,000 & Diterima \\
\hline H4 & $\begin{array}{l}\text { Quality of Work Life } \rightarrow \text { Perceived } \\
\text { Productivity }\end{array}$ & 0,017 & Diterima \\
\hline H5 & Stres Kerja $\rightarrow$ Perceived Productivity & 0,000 & Diterima \\
\hline
\end{tabular}

Ditemukan bahwa empat hipotesis dalam penelitian ini ditemukan signifikan yaitu $\mathrm{H} 2$, H3, H4 dan H5. Sedangkan satu hipotesis tidak berpengaruh yaitu H1. Menurut jalur kausal pada Tabel 5, quality of work life (P value $=0,017)$ dan stres kerja $(\mathrm{P}$ value $=0,000)$ ditemukan memiliki pengaruh yang signifikan terhadap perceived productivity. Selain itu, psychological well being ( $\mathrm{P}$ value $=0,000)$ ditemukan memiliki pengaruh yang signifikan terhadap perceived productivity. Apabila melihat $\mathrm{P}$ value yang dihasilkan dari jalur kausal dapat disimpulkan bahwa terdapat pengaruh simultan antara quality of work life, stres kerja dan psychological well being terhadap perceived productivity.

Hasil penelitian menunjukkan bahwa tenaga kesehatan yang memiliki quality work of life yang baik belum 
tentu memiliki psychological well being yang baik, dimana nilai C.R. sebesar 0,643 dan nilai $(\mathrm{p}=0,521 \geq 0,05)$, artinya tidak terdapat pengaruh antara quality of work life terhadap psychological well being. Hal ini dapat terjadi dikarenakan dalam masa pandemi covid-19 membuat kecemasan tenaga kesehatan dalam melakukan pekerjaan yang berkaitan dengan covid-19 dan selain itu pula adanya faktor yang mempengaruhi kesejahteraan psikologis tenaga kesehatan dalam bekerja dalam masa pandemi covid-19 seperti kecemasan akan tertular dan kecemasan menularkan ke orang lain terutama kepada keluarga. Terkadang seorang karyawan menunjukkan kualitas kerja yang baik namun bisa berbanding terbalik dengan kesejahteraan psikologis karena konteks kesejahteraan psikologis sangat luas dan dipengaruhi oleh berbagai faktor baik faktor internal dan faktor eksternal. Kesejahteraan psikologis seorang karyawan bukan hanya terkait kualitas bekerja di suatu perusahaan namun juga dipengaruhi oleh faktor lain seperti faktor keluarga, faktor lingkungan luar, dan faktor hubungan dengan orang lain.

Stres kerja memiliki hubungan terhadap psychological well being dimana pengaruh antara stres kerja dengan psychological well being terdapat nilai CR sebesar 6,269 $(p=0,00 \leq 0,05), \quad$ sehingga dikatakan apabila stres kerja meningkat maka akan terjadi penurunan psychological well being pada tenaga kesehatan yang bekerja selama dalam masa pandemi covid-19.

Psychological well being merupakan suatu gambaran kesejahteraan psikologis yang dimiliki oleh seseorang. Ketika seorang tenaga kesehatan memiliki psychological well being yang baik maka dapat dipastikkan bahwa dia pun memiliki stres kerja yang rendah/adaptif.

Psychological well being memiliki pengaruh terhadap perceived productivity dimana tingkat signifikansi 0,000 yang kurang dari 0,05. Artinya, jika tenaga kesehatan memiliki psychological well being yang tinggi, maka akan meningkatkan perceived productivity dalam bekerja. Psychological well being memberikan gambaran bagaimana seseorang memiliki kesejahteraan psikologis. Rumah sakit sebagai salah satu fasilitas pelayanan pasien dengan covid19 tentunya akan melakukan berbagai upaya untuk meningkatkan psychological well being tenaga kesehatan dalam bekerja karena tidak dapat dipungkiri bahwa dengan psychological well being yang tinggi dari tenaga kesehatan dalam bekerja maka akan menghasilkan perceived productivity yang baik dan tentunya hal ini akan berdampak kepada kinerja rumah sakit.

Quality of work life memiliki pengaruh terhadap perceived productivity dimana 
Tenaga Kesehatan Selama Pandemi: Pentingnya Peran Psychological Well Being sebagai Mediasi Quality of Work Life dan Stres Kerja terhadap Perceived Productivity dalam Masa

Pandemi Covid-19 di Rumah Sakit Swasta Jakarta

tingkat signifikansi 0,017 yang kurang dari 0,05 . Artinya, jika tenaga kesehatan memiliki quality of work life yang tinggi, maka akan meningkatkan perceived productivity dalam bekerja. Quality of work life yang baik akan mempengaruhi perceived productivity karena seseorang yang memiliki kualitas kehidupan kerja di dalam perusahaan mampu memberikan hasil pekerjaan yang dikehendaki dalam arti menyelesaikan beberapa cara ideal dari suatu penampilan aktivitas, mampu menyelesaikan siklus aktivitas yang diselesaikan, dan mampu aktivitas menyelesaikan suatu pekerjaan dalam waktu yang ditentukan serta mampu untuk memasiklamlkan waktu yang tersedia untuk aktivitas lain.

Stres kerja memiliki pengaruh terhadap perceived productivity dimana tingkat signifikansi 0,000 yang kurang dari 0,05. Hasil ini menunjukkan bahwa variabel stres kerja berpengaruh positif signifikan terhadap variabel perceived productivity. Artinya, jika tenaga kesehatan memiliki stres kerja yang rendah, maka akan meningkatkan perceived productivity dalam bekerja. Stres kerja merupakan suatu tanggapan adaptif yang ditengahi oleh proses psikologis dimana suatu konsekuensi dari setiap kegiatan, situasi, atau kejadian yang membebani tuntutan psikologis atau fisik yang berlebihan terhadap seseorang sehingga memicu terjadinya suatu ketegangan yang menyebabkan ketidakseimbanga $\mathrm{n}$ fisik dan psikis yang bersumber baik dari individu atau organisasi berpengaruh terhadap perilaku karyawan dalam menunjukkan kinerjanyanya dalam bekerja. Dapat diartikan bahwa karyawan yang memiliki stres atau koping yang maladaptif maka tidak mampu memberikan perceived productivity yang baik ataupun sebaliknya.

Apabila melihat hubungan kausalitas dengan jalur penelitian ini maka terdapat hubungan simultan antara quality of work life dan stres kerja terhadap perceived productivity yang dimediasi oleh psychological well being. Quality of work life tidak secara langsung atau signifikan mempengaruhi psychological well being karena adanya berbagai faktor yang dapat mempengaruhi psychological well being seorang karyawan dalam bekerja di suatu organisasi, namun dapat dipastikkan bahwa karyawan yang memiliki psychological well being yang baik mampu menunjukkan kinerjanya dalam bekerja, sehingga dapat dikatakan bahwa quality of work life dapat mempengaruhi perceived productivity melalui psychological well being. Stres kerja yang dialami seorang karyawan dalam bekerja akan mempengaruhi psikologisnya juga dalam bekerja dimana ketegangan psikis yang dialami membuat karyawan tidak mampu memberikan koping yang adaptif sehingga

mencetus 
ketidaksejahteraan psikologis, dan dengan psychological well being yang rendah akan mempengaruhi pencapaian kinerja seorang karyawan baik dari segi kuantitas kerja, kualitas kerja, dan ketepatan waktu.

\section{Kesimpulan}

Terdapat terdapat pengaruh simultan antara quality of work life dan stres kerja terhadap kinerja karyawan yang dimediasi oleh psychological well being, sehingga dikatakan bahwa apabila terjadi peningkatan quality of work life dan penurunan stres kerja maka akan meningkatkan kinerja karyawan yang dimediasi oleh peningkatan psychological well being pada tenaga kesehatan yang bekerja selama pandemi covid-19.

\section{BIBLIOGRAFI}

Abdurrahman, S. T., Mbanaso, O., Lawson, L., Oladimeji, O., Blakiston, M., Obasanya, J., Dacombe, R., Adams, E. R., Emenyonu, N., \& Sahu, S. (2015). Testing Pooled Sputum With Xpert Mtb/Rif For Diagnosis Of Pulmonary Tuberculosis To Increase Affordability In Low-Income Countries. Journal of Clinical Microbiology, 53(8), 25022508. Google Scholar

Abid, M., Scheffran, J., Schneider, U. A., \& Ashfaq, M. (2015). Farmers' Perceptions Of And Adaptation Strategies To Climate Change And Their Determinants: The Case Of Punjab Province, Pakistan. Earth System Dynamics, 6(1), 225-243. Google Scholar

Alwi, U. (2016). Implementasi Pendidikan Islam Dalam Keluarga Nelayan (Studi Pada Sepuluh Keluarga Nelayan Di Desa Bonto Manai Kecamatan Labakkang Kabupaten Pangkep).
Universitas Islam Negeri Alauddin Makassar. Google Scholar

Bouchra, B., Toufik, H., Fouad, A., Fadia, B., Kamal, B., \& Rachid, B. (2020). Retrospective Study Of Tuberculosis In The Province Of Kenitra (Morocco). Advances In Infectious Diseases, 10(4), 181-187. Google Scholar

Cascio, W. F. (2006). The Economic Impact Of Employee Behaviors On Organizational Performance. In America At Work (Pp. 241-256). Springer. Google Scholar

Cooper, E., \& Uzun, H. (2019). Corporate Social Responsibility And Bankruptcy. Studies In Economics And Finance, 36(2), 130-153. Google Scholar

Ferdinand, R. F. (2008). Validity Of The $\mathrm{Cbcl} / \mathrm{Ysr}$ Dsm-Iv Scales Anxiety Problems And Affective Problems. Journal Of Anxiety Disorders, 22(1), 126-134. Google Scholar

Gibson, D. G. (2011). Enzymatic Assembly Of Overlapping Dna Fragments. Methods In Enzymology, 498, 349-361. Google Scholar

Hair, J. F., Black, W. C., Babin, B. J., Anderson, R. E., \& Tatham, R. L. (2014). Multivariate Data Analysis, New International Edition. Harlow: Pearson Education. Google Scholar

Haryono, A., Mudjiarto, M., Wahyuni, N., \& Triatmanto, B. (2021). Competency Improvement Of Cooperative Managers To Improve Members' Welfare By Implementing Business Strategies. Management Science Letters, 11(3), 975-982. Google Scholar

Haryono, S. (2016). Metode Sem Untuk Penelitian Manajeman Dengan Amos Lisrel Pls (Vol. 53, Issue 9). Google Scholar

Kusuma, F. A., \& Sugiarsi, S. (2010). Analisis Kelengkapan Data Penunjang 
Tenaga Kesehatan Selama Pandemi: Pentingnya Peran Psychological Well Being sebagai Mediasi Quality of Work Life dan Stres Kerja terhadap Perceived Productivity dalam Masa

Pandemi Covid-19 di Rumah Sakit Swasta Jakarta

Tahun 2010 Dalam Penentuan Kode Diagnosis Utama Hypertensioncomplicating Pregnancy Pasienrawat Inap Di Rsud Wonogiri. Rekam Medis, 4(1). Google Scholar

Laxman, N., Mallmin, H., Nilsson, O., \& Kindmark, A. (2017). Mir-203 And Mir320 Regulate Bone Morphogenetic Protein-2-Induced Osteoblast Differentiation By Targeting Distal-Less Homeobox 5 (Dlx5). Genes, 8(1), 4. Google Scholar

Mathis, R. L., \& Jackson, J. H. (2006). Human Resource Management: Manajemen Sumber Daya Manusia. Terjemahan Dian Angelia. Jakarta: Salemba Empat. Google Scholar
Prateek, G. V, Skog, I., Mcneely, M. E., Duncan, R. P., Earhart, G. M., \& Nehorai, A. (2017). Modeling, Detecting, And Tracking Freezing Of Gait In Parkinson Disease Using Inertial Sensors. Ieee Transactions On Biomedical Engineering, 65(10), 21522161. Google Scholar

Robbins, M., Judge, A., \& Maclachlan, I. (2009). Sirna And Innate Immunity. Oligonucleotides, 19(2), 89-102. Google Scholar

Ryff, C. D., \& Keyes, C. L. M. (1995). The Structure Of Psychological Well-Being Revisited. Journal of Personality And Social Psychology, 69(4), 719. Google Scholar

\section{Copyright holder:}

Yohanes Ariyanto Seno, Rina Anindita, Idrus Jus'at (2022)

First publication right:

Jurnal Health Sains

This article is licensed under:

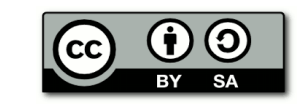

